\title{
THE IMPACT OF REDUCTION SMES TAX ON THE SMES GROWTH CASE STUDY IN PADANG CITY
}

\author{
Yuli Ardiany $^{1^{*}}$, Melli Herfina ${ }^{1}$, Sri Yuli Ayu Putri² \\ ${ }^{1}$ Akademi Akuntansi Indonesia Padang \\ ${ }^{2}$ Universitas Ekasakti \\ yuliardiany@gmail.com*
}

\begin{abstract}
In 2018 the government agreed to only reduce the tax rate to 0.5 percent. This provision is stated in Government Regulation 23/2018. The purpose of this study is to look at the impact of reducing SMEs tax rates on the growth of SMEs in the city of Padang. This type of research is comparative. Data collection techniques in this study are documentation techniques. The population in this study is the SMEs of Padang City the sampling method is purposive sampling. The analytical method used is the analysis of independent sample t-test. The results showed that the average number of SMEs in 2016 and 2017 or before the reduction in tax rates was 31,418.33, where the values in 2016 and 2017 were lower than in 2018 and 2019 at 32,417.33. This shows that there was an increase in the number of SMEs after the reduction in the SMEs tax rate. The significance level of 2-tailed obtained indicates the probability of a significance level of 0.966.
\end{abstract}

Keywords: SMEs; SMEs tax rates; Padang city; Tariff reduction

\section{INTRODUCTION}

Micro, Small and Medium Enterprises (SMEs) play an important role in the economic growth of a country. The reason is that most smallscale businesses are not too dependent on large capital or external loans in dollar terms. So, when there is exchange rate fluctuations, small-scale companies do not have the potential to experience crisis impact. The development of Micro, Small and Medium Enterprises (SMEs) has proven to be the main driver dynamic, can increase or decrease. SMEs in Padang City, which consists of of the real sector which has a direct effect on national economic growth. According to data from the Central Statistics Agency, the number of Indonesian SMEs in 2013 was $57,895,721$ units, while the growth in the number of Indonesian SMEs that year was 2.41 percent. According to the KUMKM News (2016: 5), the contribution of SMES to the formation of Gross Domestic Product (GDP) from 2009-2013 reached 57.6 percent per year, with an average growth of 6.7 percent. The number of SMEs actors is 11 Districts, data obtained from the Padang City Cooperative and SMEs Service that the number of SMEs 
EAJ (Economics and Accounting Journal) - Vol. 3, No. 3, Sept 2020 -Ardiany, Herfina, Putri

players in the city of Padang in 2018 was 2,953 SMEs.

Finance Minister Sri Mulyani Indrawati in www.kemenkeu.go.id said that tax is the national backbone. As one of the fiscal instruments, tax has an important role to develop the country and support the running of the government. As for what is included in the object of income tax according to Article 2 of Law no. 36 of 2008are individuals, individuals who have an undivided inheritance, business entities and permanent forms are objects of income tax. Therefore, as the owner of SMEs, he is obliged to pay taxes, namely the SMEs Tax.

Government Regulation Number 46 of 2013 concerning Income Tax on Income from Businesses Received or Obtained by Taxpayers with Certain Gross Turnover was issued by the government in mid-2013. In this government regulation, it is aimed at SMEs with a gross circulation of 4.8 billion in one year, where the tax rate imposed is $1 \%$ of the gross circulation.

Pros and cons a related to Government Regulation Number 46 of 2013 itself has also been buzzing for a long time. The aspect of justice is one of the cons that is often highlighted given the income tax Pemerintah No 46 tahun The reduction of the SMEs tax impacts rate is a special attraction for SMEs to enter the tax administration, thereby increasing the Indonesian taxation database. Therefore this study looks at the impact of reducing SMEs tax rates on the growth of SMEs in the city of Padang. So that with the incentive of reducing SMEs tax rates can encourage the creation of more and more SMEs in City of Padang.

Gap of research

Previous studies have only investigated the perception of SMEs, investigated the perception of the general public on tax reduction, but this study looks at how the growth of the umkm after the decrease in the general public tax rate in the city of Padang. So this research of reducing SMEs tax rates can input to goverment about growth SMEs in Padang City

2013 is included in the final tax. tends to be a way of tax avoidance by expand their businesses so they are not subject to higher tax rates.

Finally in 2018 the government agreed to only reduce the tax rate to 0.5 percent. This provision is stated in Government Regulation No. 23 of 2018. Fiscal incentives in the form of reducing SMEs tax rates would certainly be a breath of fresh air for them. Because, automatically the taxes they pay are lower than what they previously paid. Entrepreneurs will get additional capital savings that can be used to develop their businesses, especially for entrepreneurs who are just starting. In addition, this will also make entrepreneurs more competitive.

\section{LITERATURE REVIEW}

1. Tax

Mardiasmo (2011) states that the definition of tax is the people's contribution to the State treasury based on the law (which can be enforced) without receiving lead services (contrapretation) which can be directly demonstrated and which are used to pay for general expenses.

According to Burton and Ilyas (2013) the tax is in the form of direct or indirect assistance imposed by the public power of the population or an item. This is useful to cover government spending and it can be concluded that the tax is a collection from the public which will 
EAJ (Economics and Accounting Journal) - Vol. 3, No. 3, Sept 2020 -Ardiany, Herfina, Putri

later be used for the benefit of the country.

Based on Law No. 28 of 2007 concerning the Third Amendment to Law Number 6 of 1983 concerning General Provisions and Tax Procedures is a mandatory contribution to the state owed by individuals or compelling bodies under the Law, with no direct compensation and used for State needs for the greatest prosperity of the people.

Based on several opinions it is taxpayer contributions that must be paid to the state treasury under the law to finance all state expenditures are the definition of tax.

2. Income Tax

According to Law Number 28 of 2007 regarding General Provisions and Tax Procedures, income tax is a tax on income received by taxpayers. It is intended that income is any additional economic capability received or obtained by taxpayers, both originating from Indonesia and from outside Indonesia, which can be used for consumption or to increase the wealth of the taxpayer concerned by name and in any form.

According to Law Number 36 of 2008 concerning Income Taxes, domestic corporate taxpayers with a gross circulation of up to $\mathrm{Rp}$ $50,000,000,000$ (fifty billion rupiahs) receive facilities with a tariff reduction of $50 \%$ (fifty percent) and a tariff of $25 \%$ (twenty five percent) which is levied on Taxable Income from the gross circulation portion of up to $\mathrm{Rp}$ $4,800,000,000$ (four billion eight hundred million rupiah).

3. Micro, Small and Medium Enterprises (SMEs)

In the Indonesian economy, Micro, Small and Medium Enterprises (SMEs) are the largest group of businesses. As for some of the criteria used to define the definition and criteria for Micro, Small and Medium Enterprises as regulated in Law Number 20 of 2008 are.

a. Micro business

Criteria for micro business groups are productive businesses owned by individuals and / or individual business entities that meet the criteria for micro businesses as regulated in this Law. Micro business is a business that has a turnover of Rp. 0 to Rp. 300 Million per year per year.

b. Small business

Criteria for small-scale business is a productive economic business that stands alone, which is carried out by individuals or business entities that are not subsidiaries or branch companies that are owned, controlled, or become a part of either directly or indirectly of medium-sized businesses or large businesses that meet the criteria small businesses as referred to in this Act. Small businesses are businesses that have a turnover of Rp. 300 Million up to Rp. 2.5 Billion Rupiah per year.

c. Medium Business

Criteria for medium-scale businesses are productive economic businesses that stand alone, which are carried out by individuals or business entities that are not subsidiaries or branch companies that are owned, controlled, or become a part either directly or indirectly with small businesses or large businesses with a net worth or annual sales results as regulated in this Law. Medium-sized businesses are businesses that have a turnover of $\mathrm{Rp} 2.5$ billion to $\mathrm{Rp} 50$ billion per year.

4. Government Regulation Number 46 of 2013

Government Regulation Number 46 of 2013 is a regulation issued by the 
EAJ (Economics and Accounting Journal) - Vol. 3, No. 3, Sept 2020 -Ardiany, Herfina, Putri

government to provide convenience for individual taxpayers and corporate taxpayers who have a certain gross income. The imposition of PPh is based on the gross circulation of the business within 1 (one) year. The related gross circulation does not exceed Rp. 4.8 billion in 1 (one) year. Basically, all taxpayers both individuals and entities (except those in the form of Permanent Business Entity (BUT) with gross circulation that meet the criteria of NonBUT taxpayers who receive income from business, not including income from services in connection with free work, with gross circulation no more than Rp. 4.8 billion in 1 fiscal year.

Basically, all taxpayers both individuals and entities (except those in the form of Permanent Business Entity (BUT) with gross circulation that meet the criteria of Non-BUT taxpayers who receive income from business, not including income from services in connection with free work, with gross circulation no more than Rp. 4.8 billion in 1 fiscal year.

The object of PP No. 46 is income from business received or obtained by taxpayers with gross turnover (turnover) which does not exceed Rp4.8 billion in 1 tax year. Gross turnover (turnover) is the gross turnover (turnover) of all outlets, counters, outlets or the like both the center and its branches. Tax payable and must be paid is $1 \%$ of the total gross turnover (turnover).

5. Government Regulation Number 23 of 2018 (PP No. 23 of 2018)

Government Regulation Number 23 of 2018takes effect from July 1 2018, where this government regulation is a regulation regarding income or income from business obtained by taxpayers who have a certain gross turnover in one tax year.

PP No. 46 of 2013 is a government regulation in lieu of Government Regulation Number 46 of 2013, where the final $\mathrm{PPh}$ rate for MSMEs of 1 percent which is calculated based on gross income (turnover) is for MSMEs with a turnover of less than IDR 4.8 billion in a year. The time limit for this stipulated tax incentive policy is different for various tax subjects.

The half percent tax rate only applies to:

1. SMEs which have gross turnover (turnover) do not exceed Rp. 4.8 billion in one tax year. These include trade businesses, service industries such as grocery stores / stalls / grocery stores, clothing, electronics, workshops, tailors, food stalls or restaurants, salons, and other businesses

2. Valid for conventional or offline SMEs or those selling in online stores (marketplaces and social media)

The use of this special tariff also has a time limit, in accordance with PP Number 23 Year 2018, including:

1. For Individual Taxpayers for 7 years

2. Corporate taxpayers in the form of cooperatives, limited partnership or firms for 4 years

3. Corporate taxpayers in the form of limited liability companies (PT) for 3 years.

When the deadline is closed, SMEs run by individual taxpayers, corporate taxpayers and PT taxpayers can no longer enjoy this low rate. They must keep books or financial reports neatly organized, and pay income tax based on general rates according to the Income Tax Law. The time period is calculated since the tax year the regulation applies to the old taxpayer (WP), and since the tax year is registered for the new WP.

6. Hypothesis Development

In the SMEs sector, the income tax that is imposed is different from the general income tax provisions. This is contained in Government Regulation Number 23 of 2018 concerning Income Taxes on Income from Businesses Received or Obtained by Taxpayers with Certain Gross Circulations. This regulation itself 
EAJ (Economics and Accounting Journal) - Vol. 3, No. 3, Sept 2020 -Ardiany, Herfina, Putri

is a substitute for the previous regulation, namely Government Regulation Number 46 of 2013 which has been in force since July 2013.

The main difference between the two regulations is the tariff charged for the SMEs tax. In the previous regulation, the tariff was $1 \%$ of the total turnover obtained. In the latest regulation, the applicable tariff is $0.5 \%$ of the turnover obtained by SMEs business actors. Of course, this rate reduction will affect the SMEs industry. The final $0.5 \%$ income tax is itself a real effort by the government to support the development of the SMEs industry in Indonesia. With the application of a small tax, SMEs can focus more on developing their business, without being burdened by tax obligations that are too large and might be burdensome.

From this, the formulation of the proposed hypothesis is as follows:

Ha: The growth of SMEs after the reduction of the SMEs tax rate in 2018 is higher than before the reduction of the SMEs tax rate in 2018.

\section{RESEARCH METHOD}

This research is a comparative study. Comparative research according to Ghozali (2011) is a study that compares the state of one or more variables in two or more different samples, or two different times. This study compares the growth of SMEs before the reduction of the SMEs tax rate and after the reduction of the SMEs tax rate.

\subsection{Data Collection Techniques}

The data collection technique in this study is the documentation technique that is collecting data by taking data from notes, reports in accordance with the problem under study. In this case the documentation was obtained from the growth of the number of SMEs from 2016 to 2019 and the method of calculating the Padang City SMEs tax.

\subsection{Operational Definitions of Variables}

The growth of SMEs is the growth of micro-businesses which are productive businesses owned by individuals and / or individual business entities that have micro-business criteria as regulated in the law, then small-scale businesses are independent economic productive businesses that are carried out by individuals or business entities which is opened is a subsidiary or not a subsidiary that is owned, controlled or become a part, either directly or indirectly, from a medium-sized or large-scale business that meets the criteria for small businesses as referred to in the Act (Law Number 20 of 2008).

SMEs tax rate reduction is a new tax regulation contained in PP No. 23 of 2018 , where the final pph rate drops to $0.5 \%$

\subsection{Sample Collection Techniques}

The population in this study is the Padang City SMEs. which is taken as a sample is the last 4 years from 20162019. The sample is part of the number and characteristics possessed by the population. Samples are subsets of populations whose members are referred to as subjects while members of the population are elements of the population.

So in this research the sampling method is using purposive sampling technique with criteria:

a. SMEs which have gross turnover (turnover) do not exceed Rp4.8 billion in one tax year according PP Nomor 23 Tahun 2018. These include trade businesses, service industries such as grocery stores / kiosks / grocery stores, clothing, electronics, workshops, 
EAJ (Economics and Accounting Journal) - Vol. 3, No. 3, Sept 2020 -Ardiany, Herfina, Putri

tailors, food stalls or restaurants, salons, and other businesses

b. Valid for conventional or offline SMEs or those selling in online stores (marketplace and social media)

\subsection{Data Analysis Techniques}

\section{Normality test}

Normality test aims to test whether in the regression model, confounding or residual variables have a normal distribution (Ghozali, 2011). Regression models that have normal or near normal data distribution are said to be good regression models. The normality of a data can be detected by looking at the spread of data (points) on the diagonal axis of the normal plot graph, looking at the histogram graph of the residual, or using the Kolmogorov-Smirnov (K-S) non-parametric statistical test. The basis for decision making for normal plot graph analysis is as follows (Ghozali, 2011):

a. If the data spreads around the diagonal line and follows the direction of the histogram line, towards the normal distribution pattern, the regression model meets the normality assumption.

b. If the data spreads far from the diagonal line and or does not follow the diagonal line or the histographic line, the regression model does not meet the assumption of normality.

2. Independent T-Test
Independent T-Test is done by comparing the difference between the two mean values with the standard error of the difference in the mean of the two samples (Ghozali, 2011)

Independent T-Test used in this study is paired sample t-test which is used to test whether there are differences in the average of the two related samples. Analysis of independent sample t-test is one part of the parametric inferential statistics (different test) used to analyze data or samples that are not interconnected (Algifari, 2000). The requirements that are carried out before conducting a different test with the analysis of one sample t-test are that the data tested must be quantitative data, the data must be normally distributed, and the data must be similar or homogeneous (Siregar, 2005).

\section{RESULTS AND DISCUSSION}

\subsection{Results}

1. Normality test

In this test the significance value of Kolmogorov-Smirnov if it is greater than 0.05 then the data is normally distributed, but if the significance value is below 0.05 indicates that the tested variables are not normally distributed (Ghozali, 2011).

From table 1 it can be seen that the Kolmogorov-Smirnov value for the $1 \%$ tax rate is 0.374 and for the $0.5 \%$ tax rate is 0.374 . Because the KolmogorovSmirnov value is greater than 0.05 , HA is rejected, which means the data is normallydistributed.

Table 1: Result of Normality Test

\begin{tabular}{|l|c|r|r|r|r|r|r|}
\hline \multicolumn{2}{|c|}{ Tests of Normality } \\
\hline \multicolumn{2}{|c|}{} & \multicolumn{2}{|c|}{ Kolmogorov-Smirnov } & \multicolumn{3}{|c|}{ Shapiro-Wilk } \\
\cline { 3 - 9 } \multicolumn{2}{|c|}{ Pajak } & $\begin{array}{c}\text { Statis } \\
\text { tic }\end{array}$ & df & Sig. & $\begin{array}{l}\text { Statis } \\
\text { tic }\end{array}$ & df & Sig. \\
\hline $\begin{array}{l}\text { Jumlah } \\
\text { SMES }\end{array}$ & $1 \%$ & 0,374 & 6 & 0,009 & 0,705 & 6 & 0,007 \\
\cline { 2 - 9 } & $0,5 \%$ & 0,374 & 6 & 0,009 & 0,705 & 6 & 0,007 \\
\hline
\end{tabular}


EAJ (Economics and Accounting Journal) - Vol. 3, No. 3, Sept 2020 -Ardiany, Herfina, Putri

Source : Output SPSS (2020)

Table 2: Result of Independent T-Test

\begin{tabular}{|l|r|r|r|r|c|}
\hline \multicolumn{7}{|c|}{ Group Statistics } \\
\hline \multicolumn{2}{|c|}{ Pajak } & $\mathrm{N}$ & Mean & $\begin{array}{c}\text { Std. } \\
\text { Deviation }\end{array}$ & Std. Error Mean \\
\hline \multirow{3}{*}{$\begin{array}{l}\text { Jumlah } \\
\text { SMES }\end{array}$} & $1 \%$ & 6 & $31.418,33$ & $38.640,32$ & $15.774,85$ \\
\cline { 2 - 7 } & $0,5 \%$ & 6 & $32.417,33$ & $39.873,71$ & $16.278,37$ \\
\hline
\end{tabular}

\begin{tabular}{|c|c|c|c|c|c|}
\hline \multicolumn{6}{|c|}{ Independent Samples Test } \\
\hline & & $\begin{array}{l}\text { Levene's } \\
\text { Test for } \\
\text { Equality of }\end{array}$ & \multicolumn{3}{|c|}{ t-test for Equality of Means } \\
\hline & & $\mathrm{F}$ & $\mathrm{t}$ & $\mathrm{df}$ & $\begin{array}{l}\text { Sig. (2- } \\
\text { tailed) }\end{array}$ \\
\hline \multirow{2}{*}{$\begin{array}{c}\text { Jumlah } \\
\text { SMES }\end{array}$} & $\begin{array}{c}\text { Equal } \\
\text { variances } \\
\text { assumed }\end{array}$ & 0,0185 & $-0,044$ & 10 & 0,966 \\
\hline & $\begin{array}{c}\text { Equal } \\
\text { variances not } \\
\text { assumed }\end{array}$ & & $-0,044$ & 10 & 0,966 \\
\hline
\end{tabular}

\section{Independent T-Test}

After conducting a normality test, a different T-test is performed. The hypothesis proposed states that there is a difference in the growth of SMEs after the 2018 SMEs tax rate reduction than before the 2018 SMEs tax rate reduction.

Based on table 2, the results obtained from the average difference test of SMEs growth show that statistically it is seen that there is no significant difference between the period before the 2018 SMEs tax rate reduction and after the 2018 SMEs tax rate reduction ie with a 2-tailed significance value of 0.966 at significance level of 0.05 . The $t$ value presented for the paired average difference test was -0.044 with a significance level of 2-tailed 0.966, which means the t-value was not significant because the p-value 0.966 was far greater than the level of significance set at 0.05 . Thus it can be said that empirical data does not support the proposed alternative hypothesis.

\subsection{Discussion}

In the research carried out, the sample t-test was used with the compare means analysis to be able to find out the difference in the growth rate of SMEs after the 2018 SMEs tax rate reduction than before the 2018 SMEs tax rate reduction.

The average number of SMEs in 2016 and 2017 or just before the reduction in tax rates was $31,418.33$, where the values in 2016 and 2017 were lower than in 2018 and 2019 at 
EAJ (Economics and Accounting Journal) - Vol. 3, No. 3, Sept 2020 -Ardiany, Herfina, Putri

32,417.33. This shows that there was an increase in the number of SMES after the reduction of the SMEs tax rate. The significance level of 2- tailed obtained indicates the probability of a significance level of 0.966 . These things indicate that in absolute terms, the accruals of the growth of SMEs after the reduction in the tax rates of SMEs, but there is no statistically significant difference.

An alternative hypothesis which states that the growth of SMEs after the reduction of the 2018 SMEs tax rate is higher than before the reduction of the 2018 SMEs tax rate is unacceptable. Therefore the data generated does not support the alternative hypothesis (HA).

Based on the results of the research, this hypothesis was rejected because it occurred due to lack of socialization and assistance to SMEs to carry out tax obligations. Socialization can be combined with increasing the capacity of SMEs in understanding and implementing bookkeeping standards. Bookkeeping is a separate obstacle for SMEs, especially because SMEs are dominated by microenterprises.

\section{CONCLUSION}

Tax is the national backbone. As one of the fiscal instruments, tax has an important role to develop the country and support the running of the government. In addition, taxes can also be used as instruments to stimulate the economy. As the owner of SMEs, he is obliged to pay taxes, namely the SMEs Tax.

In mid-2013 the government issued Government Regulation No. 46 of 2013 concerning Income Taxes on Income from Businesses Received or Obtained by Taxpayers with Certain Gross Circulations. This regulation is actually intended for Small and Medium Enterprises (SMEs) in Indonesia because this regulation regulates the taxation of taxpayers who have a turnover of less than 4.8 billion in one year

Prokontra related to PP 46 of 2013 itself has also been buzzing for a long time. The aspect of justice is one of the cons that is often highlighted given the income tax PP 46/2013 is included in the final tax. The final tax does not look at whether the end result of the taxpayer's business is profit or loss, as long as the taxpayer has a turnover, the taxpayer must pay tax. Finally in 2018 the government agreed to only reduce the tax rate to 0.5 percent. This provision is stated in Government Regulation 23/2018. This is expected to increase the number of SMEs.

The purpose of this study is to look at the impact of reducing SMEs tax rates on the growth of SMEs in the city of Padang. This type of research is comparative, the data collection methods used are literature review and field review. Data collection techniques in this study are documentation techniques. The population in this study was the Padang City SMEs perpetrators in 2016 - 2019 the sampling method was purposive sampling. The analytical method used is the analysis of independent sample t-test.

The results showed that the average number of SMEs in 2016 and 2017 or before the reduction in tax rates was $31,418.33$, where the values in 2016 and 2017 were lower than in 2018 and 2019 at $32,417.33$. This shows that there was an increase in the number of SMEs after the reduction in the SMEs tax rate. The significance level of 2- tailed obtained indicates the probability of a significance level of 0.966 .

An alternative hypothesis which states that the growth of SMEs after the reduction of the 2018 SMEs tax rate is higher than before the reduction of the 
EAJ (Economics and Accounting Journal) - Vol. 3, No. 3, Sept 2020 -Ardiany, Herfina, Putri

2018 SMEs tax rate is unacceptable. Therefore the data generated does not support the alternative hypothesis (HA).

\section{ACKNOWLEDGEMENTS}

We thank deputy for strengthening research and development of the ministry of research and technology /

\section{REFERENCES}

Algifari. (2000). Analysis of Regression Theory: Case Theory and Solutions. Yogyakarta: BPFE.

Benazic, M. (2006). Fiscal Policy \& Economic Activity in Croatia with A Cointegration Analysis, Ekonomski Pregled, 57(12), 882917.

Burton, B \& Ilyas . (2013). Tax Law, 6th Edition. Jakarta: Salemba Empat.

Ghozali, I. (2011). "Multivariate Analysis Application with SPSS Program". Semarang : UNDIP.

Mardiasmo.(2011).Taxes. Yogyakarta. Andi

Noor, S. \& Akhmad Soehartono, Agung Baruna Setiawan Noor. (2018). Impact Study on the Application of Final PPH $0.5 \%$ on SMES in the Framework of Achieving the 2018 Tax Revenue TARGET. SNITTBalikpapan State Polytechnic. ISBN: 978-602- 51450-1-8

Republik Indonesia. (2018). Government Regulation Number 23 of 2018 concerning Income Tax on income from business received or obtained by Taxpayers who have a certain gross turnover

Republik Indonesia. (2009). Law Number 16 of 2009 concerning general provisions and tax procedures

Republik Indonesia. (2008). Law national research and innovation agency with LLDIKTI region $X$ in accordance with the research implementation contract Number: 001 / LL10 / PG / 2020 and the novice lecturer scheme research contract Number: 002 / LPPMAAI / contract- research / 2020

Number 16 of 2009 concerning general provisions and tax procedures

Republik Indonesia. (2008). Law Number 36 of 2008 concerning Income Tax

Rosdiana, H. dan Edi, S. I. (2012). Introduction to Tax Science: Policy and Implementation in Indonesia. Jakarta. Rajawali Pers

Siregar, S.. (2005). Applied Statistics for Research. Jakarta: PT.Gramedia

Sudirman, R. \& Antong A. (2015). Taxation: Theory and Practice Approach. Malang. Empat Dua Media

Vhanmilo, V. (2018). Analysis of Compliance of SMES Taxpayers in Paying Income Taxes (Case Study at SMES in Pesisir Selatan District) [Essay]. Padang (ID). University of Andalas

Wahdi, N., Yulianti \& Christera. (2015). Analysis of the Implementation of PP No.46 of 2016 concerning SMES Tax on the growth rate of taxpayers, income tax revenue and which SMES benefits [Research Results]. Semarang (ID). PGRI University in Semarang.

Waluyo. (2011). Indonesian Taxation. Jakarta. Salemba Empat

Warta KUKM. (2016). Strengthening SMEs for quality economic growth. Vol 5 No 1-2016. ISSN No. 2338-3747.

www.kemenkeu.go.id 